\title{
In the Process of Being Bilingual of an Indonesian Child: The Phenomena of Code-Switching, Language Mixing and Borrowing
}

\author{
Lisda Nurjaleka, ${ }^{1 *}$ Rina Supriatnaningsih ${ }^{2}$ \\ ${ }^{1}$ Pendidikan Bahasa Jepang, Fakultas Bahasa dan Sastra, Universitas Negeri Semarang, \\ Sekaran, Semarang 50229, Indonesia \\ *) Corresponding Author \\ Email: lisda_nurjaleka@mail.unnes.ac.id \\ DOI: $10.18326 /$ rgt.v14i1.99-120
}

Submission Track:

Received: 14-03-2021

Final Revision: 26-05-2021

Available Online: 08-06-2021

Copyright $@ 2021$ Authors

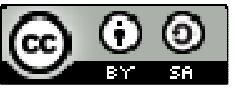

This work is licensed under a Creative Commons Attribution-ShareAlike 4.0 International License.

\begin{abstract}
The present study is a longitudinal study for approximately 26 months to the Indonesian child and has been through her second language acquisition in Japan. A Longitudinal study is a research design that involved repeated observation of the same variables over long periods. The acquisition process took place for about four years. After returning to Indonesia, the family wants to keep her second language and do some second language maintenance. While in her process to be bilingual, she experienced a process of code-switching and code-mixing in her daily lives using their mother tongue, Indonesian, and her second language, Japanese. This research focuses on how the child maintains her second language and how the bilingual process's phenomena occur through interactions in the family environment. Several language transfers from the second language to the first language occur in their daily life using Indonesian. This study uses an ethnographic research approach. Conducting ethnographic research requires a long-term process by making detailed notes about the group's behavior and beliefs from time to time. Observation and interviews are the procedures used in data collection in the field. The transfer language process is used through the code-mixing, codeswitching, and preservation process of the second language after returning home. The results saw that the child both use language systems in each language and sometimes mixed in between languages, as she has her languages.
\end{abstract}

Keywords: code-switching; language mixing; Japanese as a second language; bilingual proces 


\section{INTRODUCTION}

A phenomenon of code-switching, language mixing, or borrowing arises concerning the bilingual context. In multilingual and bilingual environments, this typically happens in societies. Many scholars studied these in terms of child bilingualism, the phenomenon of code-switching, language mixing and borrowing (Yumoto, 1996); code-switching associated with language identity and globalization (Hall \& Nilep, 2015); code-switching and borrowing focused on language contact for immigrants in Australia (Alvanoudi, 2018) and others.

Some studies estimated that nearly $70 \%$ of the world's population is bilingual and lives in a bilingual environment (Trask, 1999; Crystal, 2003). This scope of bilingualism is very closely linked to Indonesian populations. In 2019, Indonesia had approximately 1,340 ethnic groups and consists of almost 700 spoken local languages, according to BPS (Badan Pusat Statistik; Central Statistics Agency). Thus, Indonesia is considered one of the countries rich in cultural diversity. Almost all Indonesian people are bilingual because of the number of ethnic groups and local languages. On average, they can also speak Bahasa Indonesia and the local language. Unlike neighboring Malaysia, which uses English as their second language, or the Philippines. In Indonesia, English has been introduced as a foreign language in schools. Similarly, schools are free to include other foreign languages at the middle and intermediate stages, such as French, Chinese, Japanese, and others. (Noprival, Rafli \& Nurudin, 2019).

Bilingualism means an alternate use of two or more languages by the same person (Mackey, 2000, p. 27). There are two bilingual types in terms of "learning time," which are simultaneous bilingual and sequential/successive bilingual. In this study, a bilingual Indonesian child is considered a sequential bilingual process. It means that bilinguals start learning one language and then start learning another language with a time lag. According to De Houwer (2009), there is a distinction between the first and second languages because the two languages are learned step by step but in the early stages of daily contact with the two languages.

In Bilingualism, there are two levels, the individual level and the social level, according to Yamamoto (2014). The individual level is when the child experiences the acquisition of both languages personally. Meanwhile, Bilingualism is at the social level because Bilingualism transcends social, 
political, economic, and other relationships. It can then be categorized as Bilingualism at the social level. Immigrants transitioning to a new language, for example, are bound to be bilingual (sometimes more). Some immigrant groups often maintain and pass on their native language to the next generation.

Study on code-switching can be seen from various perspectives such as linguistics, psycholinguistics, and sociolinguistics. The linguistic perspective focuses more on finding universal grammar boundaries, while the psycholinguistic perspective focuses on how the linguistic system is stored and accessed in the cognitive system. Furthermore, code-switching can also be seen from a linguistic perspective that focuses on its user's social motivation. (Isurin et al., 2009). The approach can be seen from the language of interaction, according to Auer (2009), about structural and functional code-switching. Moreover, he argues that, for syntactic research, code-switching does not provide many interesting data.

Several studies on code-switching, especially in structural and grammatical aspects, are sometimes closely related to second language acquisition (SLA). The approaches or perspectives are taken to become an interesting issue to examine code-switching, language mixing, and borrowing. In certain communities, multi-lingual interactions make it possible to create social diversity amid globalization's acceleration.

This study seeks to review the Indonesian child's process started to be bilinguals in a family in a multilingual environment in terms of bilingualism, interlingual family, and language maintenance, where phenomena such as language mixing, code-mixing, and borrowing occur while in the process. The researcher's interest in the second language maintenance process is to use observations to preserve Indonesian children's language who have acquired Japanese as a second language. In multilingual communities or minority communities, this phenomenon appears often occurred. However, few studies yet analyze the perspective as a tool of second language maintenance.

\section{Language Maintenance}

Several studies have linked language maintenance to immigrants who live in certain countries and maintain their heritage language in the majority language community regarding language maintenance and code-switching phenomena. Humans have the same ability when they lose or forget language 
as they learn the language, according to Reilly (1988). Due to this lack of an environment that supports the proper use of linguistics in using a particular language, many lose language skills. For example, in some cases, children or adults who are monolingual native speakers of another language are now monolingual English speakers. They are no longer able to use their mother tongue.

Referring to second language maintenance has taken place in countries such as Canada. Harley (1994) examined how Canadian adults' second language is maintained, the French they learned in school. To maintain the language, they conduct their second language maintenance successfully with several activities. Higher initial competence and the use of a second language are often positive attempts to maintain competence. As a motivation, they also carry out a fun and interesting activities to maintain the language so that motivation is maintained in the use of the language.

$\mathrm{Yu}$ (2005) examined the language maintenance and code-switching in young Chinese immigrants influenced by family factors. It can be seen that the use of mandarin decreased after about 28 months in New Zealand as a result of the study. Some parents claim that English is used too often by their kids. Despite their parents' wish for their child to maintain their native language and parental input significance. There tends to be an early stage in code-switching among children, leading to language change.

In the language maintenance process of immigrants, this phenomenon of code-switching, code-mixing, and borrowing is evident because they live in a multi-lingual environment. It is possible to identify three types of contact situations closely related to code-switching, namely language maintenance, language shift, and language creation (Windford, 2003). Maintenance language carried out by minority groups of their native languages from generation to generation due to contact. Some changes bring more strength and prestige, such as borrowing forms, constructions, or patterns from the dominant group's language. (Alvanoudi, 2018)

\section{Code-Switching, Code-Mixing, and Borrowing in terms of sociolinguistics}

According to Poplack (2001), code-switching (CS) refers to the mixing by bilinguals (or multilingual) of or more languages in a discourse. Often, no change in the interlocutors or topic. This kind of mixing can occur at the level of 
any linguistic structure. However, it occurs within the boundaries of one sentence, constituent, or even word, which is of concern to most linguistic researchers. Code-mixing refers to all cases related to two languages' lexical and grammatical features that appear in one sentence. (Muysken, 2000)

Code-switching is discussed by linguistics scholars, including Gumperz (1982), Auer (1995), Sebba \& Wootton (1998), and others. In the multilingual repertoire, meaning should not be confused with the "social meaning" of various languages because it is often believed to exist in diglossic situations. Although code-switching has become a hallmark of bilingual communities worldwide, it has only become the center of attention among scholars in the last few decades.

Other studies have shown that bilinguals can move between languages for various reasons and contexts. The inability to find the correct word to use "to fill a linguistic need" (Pulisse and Bongaerts, 1994) or the greater availability of a word in another language are some of the reasons for using code-switching. Myusken (2000) argues that code-switching still needs to be studied more deeply regarding social explanations. It can be concluded from some of the literacy above, which includes the terms code-switching, that in addition to code-switching, there are many cases of the juxtaposition of two languages, one of which is "mixing" both languages, dialects, etc.

According to some literature, the categorization of language mixing is explained by overlapping terminology. Language mixing refers to "the merging in any verbal communication of characteristics of two or more languages" (Odlin, 1989). Odlin (1989) also added that bilingualism is often equated with language mixing and code-switching. Two separate systems are not always known to young bilinguals that mix languages (Dopke, 1992; Taeschner, 2012), so their language mixing is described as "unfocused mixing."

Some studies have also discussed borrowing transfers in Australia's ethnic language, Dyribal, which experienced friction due to the English exposure (Reported in Odlin 1989:12). Another study discusses the friction that occurs due to borrowing transfers, including several variations of the Swiss Roman by German and the Greek variations by Turkish and Norwegian, influenced by American English. (Odlin, 1989) 
When two languages are interconnected, and individuals with special communicative needs try to make the language "more similar," so to speak, fill in what is lacking in each with constructs from the other, namely by linguistic borrowing. (Baker, 2018) Words can be borrowed by one community and become part of another language as loanwords.

Several studies have also discussed children's code-switching (Meisel, 1994; Reyes, 2004; Yu, 2005; Cantone, 2007), showing that children develop bilingual communicative competence and learn to use their two languages depending on the recipient (addressee), the topic of conversation and the situation. In this study, the phenomena of code-switching, language mixing, and borrowing are seen from a sociolinguistic perspective by maintaining an Indonesian child's second language.

In the context of a family environment, these three sociolinguistic phenomena will also be associated with the choice of family language and language use. From previous research, it can be seen that family language policy and its use in the family context determine whether children become bilingual and maintain their heritage language. (Pavlenko, 2004; Dumanig, David, \& Shanmuganathan, 2013)

However, there is very little research on the implementation of codeswitching, language mixing, and borrowing in the second language maintenance context. Especially in the diaspora context, they return home to their country and maintain their second language. Apart from their native language, intercultural communication and knowledge of other languages have also been essential in recent years. An effort must therefore be made to retain Japanese as a second language. Meanwhile, the phenomenon of code-switching, language mixing, and borrowing occurred during the process.

The following research questions arise and will be the content of this paper: How are the sequential bilingual process of Indonesian Child? And are there any code-switching, language mixing, and borrowing in the process of being bilingual?

\section{RESEARCH METHOD}

Maintaining a second language in a mother language society with only one parent speaking the second language is challenging for the parent and the child. 
This case study explores this very situation over the twenty-sixth months, with their home language is Indonesian. The child's community is the mother who speaks Indonesian, Japanese, and her mother language is Sundanese. Meanwhile, the father only communicates with her in Indonesian, and his second language is English. The father only understands passively Japanese, and it is at entry-level. This study took place in Semarang city, Central Java Province, Indonesia. It is important to mention that the leading researcher received access to the participants as her mother. To better understand this reality's context, it is essential first to introduce the subject of this study and the interlocutors involved. Moreover, we also explain where the study took place and how the data was collected.

\section{Participants}

This study's subject is Shafa, a tenth-year-old Indonesian child (born of two Indonesian parents in Indonesian); she was an only child at the time of this study. Interested in developing her second language and the child's linguistic behavior, as her mother, as the lead researcher in this study, gained access to the data we have collected. The family has been lived in Japan for about four years. So, she acquired Japanese naturally in a Japanese community.

The observation begins with the main author from May 2018 until June 2020, after the family returned home from Japan, where they lived before for four years. Shafa was in grade fifth of an elementary school in Indonesia when the observation began. In Japan, she entered a public school from the first grade until the fourth grade. She acquired her second language, Japanese, in School informally. Still, she also has taken a Japanese language course formally supported by Kanazawa's city government, a city in Ishikawa Prefecture of Japan. The language course length was once a week for two hours for 1,5 years. She acquired her second language, Japanese, in her School, and she used Japanese to interact with her classmates, teachers.

Shafa's Japanese language competency is nearly fluent as she passed the Japanese Language Proficiency Test (JLPT) level N2 and has mastered 2,000 kanji and 10.000 words equivalent with JLPT level N1. After returning home to Indonesia, she takes her Japanese proficiency every six months, and each year she passed the examination bar. The N1 level criteria categorize that the person 
has sufficient for life in Japanese society. The N1 level is the highest level of the JLPT.

\section{Trustworthiness, role of the researcher and ethical consideration}

The main and lead researcher is the mother of the subject and has been observing and collecting data using videos and fieldnote within the family. The co-author interviewed the child to deliver an objective result of the interview.

To ensure the findings in this study are trustworthy, we shared the interview transcriptions with the subject to check what We had recorded and transcribed matched with their standpoints (Koelsch, 2013). Besides, as both a researcher and the participant's mother, collecting data by observing using videos and field notes inside the family. We also took follow-up interviews to ensure the data's validation. Moreover, We sought an opinion from the child. There is no conflict of interest between the researcher and the subject. I gained access directly by observed her language behavior in daily life. The family, father, and the child are fully aware and consent to the observations and followup interview.

\section{Settings}

We started the observation as a part of the longitudinal study after the family and the child returned home to Indonesia. We focused on how the child and the family maintained the child's second language, Japanese using an ethnography study approach. Our primary interest was in her experiences using code-switching, language mixing, and borrowing in the familial environment. An ethnography approach uses to look from a cultural perspective to study people's lives in their communities (Hammersley and Atkinson, 2007; Fetterman, 2010). This study's theoretical underpinnings follow a qualitative approach (Tracy, SJ., Geist-Martin, P., Putnam, L.L., \& Mumby, D.K., 2014) using an ethnographic perspective to provide a complete view of children's code-switching, language mixing, and borrowing patterns.

\section{Research Context}

This paper's primary interest is in investigating the Indonesian child and the interaction with the family members managing their way to maintain the second language. Moreover, how the process into bilingual was observed. The aim is to explore the sociolinguistic phenomena of code-switching, language 
mixing, and borrowing in empirical detail to the process of being bilingual and the family's aim to maintain her second language, Japanese, in the home language community.

We conducted fieldwork in the familial environment and her interaction with the family, focusing on bilingual interaction. Observation notes, audiorecorded interactions, and interviews with children are among the data collected.

To achieve the aims of this study effectively, as the main researcher and her mother, we use natural data by observing her in the field and sometimes crosschecks with follow-up interviews to the participants about her language behavior. We combine the data collection methods such as interviews, observations, and field notes to get the comprehensive data field and, as Dornyei (2007) suggested, how to conduct ethnography research. Johnson (1998) also emphasized that ethnography study is to "describe and interpret the culture behavior, including communicating a group's behavior." In this study, we observed a young bilingual child reveal some aspect of language behavior focusing on code-switching, language mixing, and borrowing. The primary data is taken by recording the participant and the researcher's conversation.

\section{Figure 1}

The field note design

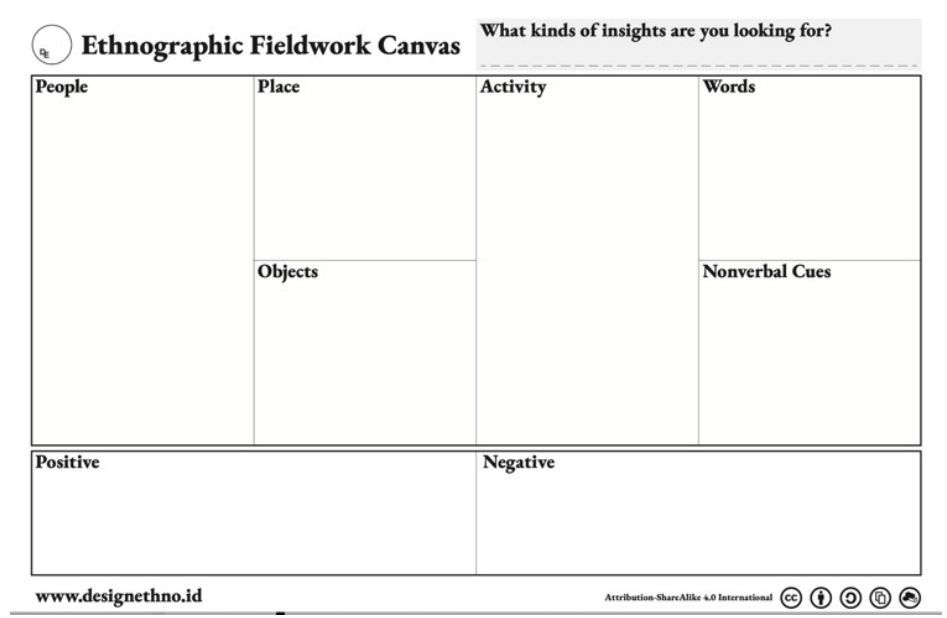




\section{Data Analysis}

The collected material was carefully transcribed and noted, and then thoroughly studied and analyzed. Some examples are given in this paper show S.R bilingual process patterns, and the researcher observed code-switching, language mixing, and borrowing. Each activity on bilingual language behavior is recorded following: 1) whether the code-switch/language mixing complies with the equivalent limitations, the grammar category, the codeswitching/code-mixing category, and, 2) whether the code-switching or codemixing can be distinguished as an activity of this analysis based on the equivalent boundaries as Poplack (1998a) described.

Moreover, the grammatical analysis categories are defined by Zentella (1997).

\section{RESULTS AND DISCUSSION}

In being a sequential bilingual, the child takes steps to keep both languages and use them daily. This study's leading researcher focused on observation on the phenomenon of code-switching, language mixing, and borrowing of Indonesian children in the family interaction. The field notes we collected from the observation categorize that the bilingual level is still individual. It means that the use of both languages has not yet reached the social aspect. As Yamamoto (2014) described, the child uses both languages personally and within the family environment.

Moreover, we noticed these phenomena of code-switching, language mixing, and borrowing between two languages from the beginning of our observation. Meanwhile, a monolingual could not have the ability to move between these languages.

\section{Language Transfer and Borrowing Occurred in the Process of Second Language Maintenance}

This stage of borrowing and transferring was observed and occurred in the subject. This study's context is that the subject's first language is Indonesian, and the second language is Japanese. The author observed her linguistic skills in using and borrowing from the second language, which was used to explain in her first language, Indonesia. 
Below are some of the sentences that categorize borrowing the Japanese term and use in Indonesian sentences. S.R. could not get a word equivalent, or she felt it difficult to translate to Indonesian.

\section{Example 1:}

“Mamah nanti nihongo nouryokushiken-nya gimana?" (translation: Mama, how about the Nihongo nouryokushiken?)

Example 2:

"Aku rikka-nya lagi belajar itu" (translation: I think I learn that rikka.)

The context of the second sentence is the use of the term "noryokushiken", which is an official language assessment for the Japanese language, known as the Japanese Language Proficiency Test (or called JLPT), and the term "noryokushiken" is more popular and general among Japanese learners. So the child uses "noryokushiken" as borrowing from her second language, Japanese, in the term she uses more familiar. Meanwhile, in example two, Shafa was talking to her mother about her homework from school. In this sentence, she borrows the Japanese word, "rikka," which means "science". This borrowing to occurred in both sentences is that the child feels more familiar and comfortable using Japanese terms. The reason for the emergence of this borrowing phenomenon is that the child is more familiar with the term "rikka" in the previous school and is not familiar with the term "IPA" in his mother tongue. This reason is based on the first time the term "rikka" was acquired by the child in the second language, Japanese. The term is felt more familiar, and it is a bit difficult to find an equivalent because the acquisition sequence process reversed.

Baker (2018) mentioned that borrowing the vocabulary is when a language or term does not get a word equivalent or is challenging to translate. In this section, the author explains how the experiences and perspectives of the child and her parents. Moreover, when two languages are related, individuals who have specials communicative needs try to make the language more similar to what is lacking in a particular language, namely by borrowing linguistics.

Another phenomenon that occurred in this second language maintenance and being bilingual is language transfer. This language transfer mainly an influence of the mother tongue to the other languages or vice versa. 
According to Odlin (1990), there are several differences between the transfer from the mother tongue (L1) to the second language (L2), where the influence of L1 can manifest itself as a transfer or borrowing. Meanwhile, the second language (L2) influence tends to manifest itself only in borrowing.

From the observation result, we can see that language transfer and borrowing were influenced by different language environments, which in this study, the child environment is her first language. It can be seen that her first language (L1) has a much stronger character and more fluently than her second language of Japanese. The author found the emergence of transfer structure semantic and syntactic structure in his daily life in Indonesian. An example is like the following sentence.

Example 3:

"Mamah, ini sekken-nya bisa disatuin lagi? Masa gimana caranya di-fukkatsuin, gimana caranya aku gak tau". (translation: Mama, this sekken - can we combined again? How we fukkatsu it? I don't know how?)

From example 3 above, there is a transfer of semantic structures and syntactic structures that affect the utterance in the native language, Indonesian. The syntactic structure here is in Indonesian interrupted by Japanese vocabulary and verbs. The word used "sekken," which means soap, and adding a suffix of "-nya" in Indonesian indicates the interruption of Indonesian sentences and Indonesian syntactic patterns. Likewise, the use of the verb "fukkatsu" in Japanese is added with an Indonesian affix "di-" and suffix "-in" in one sentence.

According to several studies, the syntactic transfer process is also found in L2 acquisition in children (Muller, 1998). If the syntactic rules differ from the two languages, the target language's syntactic expression can be affected by the second language's existing syntactic knowledge. It is resulting in a detectable syntactic transfer. So, it can be seen that children use two different languages in one utterance. Syntax rules are difficult to define due to a lack of pronunciation by bilingual children of two and three words. This syntactic transfer phenomenon is found in the L2 acquisition of children and second language maintenance from the above example.

From the observation to the subject in her daily life using her native language and Japanese's second language. Several observation categories are 
seen through linguistic structures such as semantics, syntax, and grammar categories. Marian \& Kaushanskaya (2007), in their research, explained that the phenomenon of cross-linguistic borrowing is an activity of using words from other languages openly, and language transfer means the use of semantic or syntactic structure from other languages without actively changing into that language.

From the examples given above, we can see that the phenomenon of cross-linguistic borrowing occurred as in Marian \& Kasuhanskaya's study. The syntactic rules use in example 3 are in the Indonesian language.

From the result, we can conclude that being bilingual makes it possible to switch between languages. Changing linguistic contexts can affect the coding of nouns and verbs, resulting in different cross-language interaction patterns for the two different grammar, with verb coding being more affected by language change than by noun coding.

\section{Code-switching and Language Mixing on the Process of Being Bilingual}

We use Poplack (1980) approach to categorize and differentiate between code-switching and language mixing. This code-switching is often used by someone bilingual who uses two languages in one conversation context as the norm for individual behavior. Many studies say that bilinguals switch from one language to another for various reasons and contexts. The motivation for codeswitching is that sometimes there is a lack of understanding of certain vocabulary or difficulties finding the individual's right equivalent words. Some of the code-switching classifications found in the data that the authors have collected described as follows:

\section{Situational Code-switching versus Conversational Code-switching}

Gumperz (1977) categorizes code-switching into conversational codeswitching and situational code-switching. What is meant by situational variables based on topic, interlocutor, and events that trigger code-switching? This situational code transfer is an alternation between variations that change the situation to change the existing norms.

Below are some examples of the sentences categorized as situational codeswitching, are as follows: 
Examples 4:

"Yang di sini, ocha no aji wa sukunai" (translation: this restaurant, ocha no aji wa sukunai (the taset of the tea is thin))

Examples 5:

"Nukechattayo, keluar sendiri" $\rightarrow$ aplikasi di Ipad keluar sendiri (translation: " I missed it, it's log out by themselves" $\rightarrow$ talking about an application on the Ipad is log out by themselves)

Examples 6:

"Kan sameta, dianya udah kedinginan" (translation: It's getting cold. Sameta = cold)

\section{Examples 7:}

"Itu apa? Itsu tsukatta houga ii no?" (translation: "what's that, when can it be used?")

Based on the observational notes, situational code-switching fulfills certain functions, including specifying certain things, such as in example 4, when the child discusses something secret and does not want someone to know. She expressed her opinion about the different tea tastes when in the context, they were going out to the restaurant. So, she intentionally used her Japanese so that no one in the surrounding knows what she said. Situational code-switching also functions when the speaker wants to clarify the potential or lack of understanding of something; this can be seen from example 5. It is explained when the subject talks to her mother discussing her iPad applications that often log off independently. Emphasis is done when the child has already expressed it in Japanese and emphasizes his speech again by adding the same Indonesian expression. As is the case with example 6, we can see the context of the food "oyakodon," the emphasis is placed on Indonesian for vocabulary that comes first in Japanese.

Another function of situational code-switching can be seen from example 7 when the child emphasizes something in her sentence. When in Indonesian, it is not enough, she adds and emphasizes her sentences again in Japanese. Example 7 is about soap from the Biore brand that she does not know its function.

From the examples above, we found that situational code-switching is a natural process that occurs in bilingual young people, partly due to pragmatic 
differences and understanding of their situation. When they learn a language, children learn to express what they think and communicate with other people who have particular social situations. So it can be seen that language switching is influenced by parents or people when they are interacting. These results support Grim's (2008) study on the roles of an English-French bilingual's situational code-switching.

\section{Emblematic Code-switching versus Intimate Code-switching}

From the collected data, we found several examples of emblematic codeswitching, such as:

Examples 8:

"Apa ya? Nan dakke" (translation: what is it?.... nan dakke)

Example 9:

"Mamah, sugoi yo ma” (translation: Mamah, looks it's cool_ma...)

Example 10:

"Keju oishii da mon" (translation: cheese are yummy)

Some markers occurred, such as a single noun that is often used in the language, for example, in English "honey," or several short expressions (such as: are you kidding, give me a break, you know, I mean, etc.). According to Dumitrescu (1993), these things are often a feature of emblematic codeswitching. In this case, we found several examples, such as the sentence above in the form of short expressions that are often used and code-switched. The phrase "nan dakke" is usually an expression often used when expressing a speaker's confusion. "Nan dakke" is a type of discourse marker in Japanese. Also, several phrases such as "Sugoi yo" or "oishii da mon" are cliches often used by Japanese people to say "Ohh, that is great" or "it is good," also seen as being used by the child. Several findings of code-switching sentences appear that the attachment of these expressions is felt to be appropriate and embedded in Indonesian syntax.

Meanwhile, intimate code-switching, or often referred to as intrasentential code-switching, is a code-changing category or changes ultimately to another language system within the boundaries of the main constituents, such as:

Example 11: 
"Tuh mah burung mah, tsukamaeta" (translation= look ma, the birds, it captured)

Example 12

“Aksara Jawa mah, maa 90\% oboete iru kedo, sukoshi wakaranai tokoro mo aru" (well for Javanese alphabet, I think I can remember 90\% of them. However, there's some that I still don't know)

Example 13

"Punya Salwa ga habis, atama ga kiin suru kara" (The one that Salwa has not yet dranked, she said because her head is hurt)

From the examples above, we can see that the child used many intimate code-switching. There is a change of transfer from one language to another when in one utterance. The intimate code-switching does not violate the two languages' syntactic rules; it can even be seen that the two languages' surface structures mapped to one another.

This study results support Poplack's (2001) study stating that non-fluent bilinguals often use this type of code-switching. It does not mean the inability of a bilingual who is not fluent in expressing only one language. However, it appears that, at times, the subject deliberately combines the two systems of grammar rules and is not attracted to other rules of language. This code-switching requires high competency skills for both languages. From the author's observation, several examples of sentences like the one above are deliberate subjects combining two grammar rules without overlapping each other.

We conclude that there are several models of bilingualism. We can see that code-switching and language mixing in the daily use of research subjects are bilingualism. These phenomena indicate that the child has developed a combined bilingual model system. Bilingualism or language mixing or codeswitching or language transfer and borrowing are aspects of cross-linguistics in language contact situations. Language mixing serves to fill linguistic needs and maximize communicative competence. Language mixing also offers interesting topics concerning the bilingualism model. It introduces a mixture of grammar to discourse, which is seen in code-switching, such as grammar combinations and switching languages. The observation notes also found language mixing, which is quite broad, such as intrasentential code-mixing.

Meanwhile, in perspective used by Auer $(1998,1999)$, code-mixing (or language mixing) conflicts with code-switching (or language switching) based 
on structural pragmatic considerations. Concerning code-mixing, the pragmatic content can be categorized as low enough where the structurally different code cannot be differentiated communicatively. In contrast, code-switching is relatively high, where the speaker shows awareness between two structurally differentiated codes.

The child uses only the vocabulary it has acquired and used to communicate at that moment. Language mixing is different from language switching when the language mixing process occurs without the child realizing it.

\section{CONCLUSION}

This study is an ethnographic study on maintaining the second language of an Indonesian child and focuses on how the child surviving her second language, Japanese, in a family environment. The language transfer process such as code-switching, language mixing, and borrowing was found in her interactions with the family member. Some language transfers are found from the second language to the first language or vice versa.

This language maintenance process is unique from other studies due to the special specifications that arise due to the child's second language acquisition process, even though it is a relatively short time of about four years. She then returned to the activities in her native language, even though the process of acquiring her second language cannot be said to have been completed. The environment, which plays an important role in the language acquisition process, is also the key in this study. The research focuses on the conditions and family support in terms of maintaining Japanese as a second language.

Some phenomena such as language transfer occur in adapting to the native-speaking environment and the child's efforts to maintain Japanese. So that along with this maintained process, the surviving to maintain her second language were seen. We can also summarize in our interview result that family plays a vital role in her being bilingual. The family is a social organization that allows cross-cultural and cross-generational variables to emerge.

Phenomena in language transfer stages are also found, such as codeswitching, language mixing, and borrowing. This phenomenon commonly 
appears in the bilingual and second language learning processes. Language transfer, either as active semantic or syntactic structures, is seen in everyday life when using "home language." It forms an idiolect or individual language that creates an interlanguage type. This cross between the first and second languages results in the two languages being tied to each other, resulting in an interlanguage. In this interlanguage stage, we found the phase of developing bilingualism. Moreover, the bilingual child tends to have metalinguistic abilities, cognitive flexibility, conceptual elaboration, divergent thinking, and cognitive pluralism. Therefore, Code-switching, code-mixing in the form of other language patterns are not commonly found in monolingualism.

\section{Acknowledgment}

The researchers would like to gratefully acknowledge the Dean of Faculty of Language and Art, Universitas Negeri Semarang, and vice dean of academics for their support and grant given in finishing this research.[rgt]

\section{REFERENCES}

Alvanoudi, A. (2018). Language contact, borrowing and code switching: A case study of Australian Greek.Journal of Greek Linguistics, 18(1), 33-44. https://doi.org/10.1163/15699846-01701001

Auer, P. (1995). The pragmatics of code-switching: A sequential approach. One speaker, two languages: Cross-disciplinary perspectives on codeswitching, 115-135. https://doi.org/10.1017/CB09780511620867.006

Auer, P. (1999). From codeswitching via language mixing to fused lects: Toward a dynamic typology of bilingual speech. International journal of bilingualism, 3(4), 309-332. $\quad$ https://doi.org/10.1177/ 13670069990030040101

Auer, P. (2009). On-line syntax: Thoughts on the temporality of spoken language. Language Sciences, 31(1), 1-13. https://doi.org/10.1016/j.langsci. 2007.10.004

Baker, M. (2018). In other words: A coursebook on translation. Routledge.

Caldas, S. J. (2006). Raising bilingual-biliterate children in monolingual cultures (Vol. 57). Multilingual matters.

Cantone, K. F. (2007). Code-switching in bilingual children(Vol. 296). Springer. 
Crystal, D. (2003). English as a global language. Ernst Klett Sprachen.

De Houwer, A. (2009). An introduction to bilingual development. Multilingual Matters.

Döpke, S. (1992). One parent one language: An interactional approach (Vol. 3). John Benjamins Publishing.

Dörnyei, Z. (2007). Creating a motivating classroom environment. In International handbook of English language teaching (pp. 719-731). Springer.

Dumanig, F. P., David, M. K., \& Shanmuganathan, T. (2013). Language choice and language policies in Filipino-Malaysian families in multilingual Malaysia. Journal of Multilingual and multicultural Development, 34(6), 582596. https://doi.org/10.1080/01434632.2013.784323

Fetterman, D. M. (2010). Walking softly through the wilderness: Ethics. Ethnography: Step-by-step. SAGE Publications.

Grim, F. (2008). The topics and roles of the situational code-switching of an English-French bilingual.Journal of French Language Studies, 18(2), 189.

Gumperz, J. J. (1977). The sociolinguistic significance of conversational codeswitching. RELC Journal,8(2), 1-34. https://doi.org/10.1177/ 003368827700800201

Gumperz, J. J. (1982). Discourse strategies (No. 1). Cambridge University Press.

Hall, K., \& Nilep, C. (2015). 28 Code-Switching, Identity, and Globalization. The Handbook of Discourse Analysis, 2, 597. https://doi.org/10.1002/ 9781118584194.ch28

Harley, B. (1994). Maintaining French as a second language in adulthood. Canadian Modern Language Review, 50(4), 688-713. https://doi.org/ 10.3138/cmlr.50.4.688

Isurin, L., Winford, D., \& De Bot, K. (Eds.). (2009). Multidisciplinary approaches to code switching (Vol. 41). John Benjamins Publishing.

Johnson, K. (1998). Deinstitutionalising women: An ethnographic study of institutional closure. Cambridge University Press.

Koelsch, L. E. (2013). Reconceptualizing the member check interview. International journal of qualitative methods, 12(1), 168-179. https:// doi.org/10.1177/160940691301200105

Mackey, W. F. (2000). The description of bilingualism. Language, Communication and Education, 291. 
Marian, V., Blumenfeld, H. K., \& Kaushanskaya, M. (2007). The Language Experience and Proficiency Questionnaire (LEAP-Q): Assessing language profiles in bilinguals and multilinguals. Journal of speech, language, and hearing research, 50(4), 40-967. https://doi.org/10.1044/10924388(2007/067)

Meisel, J. M. (Ed.). (1994). Bilingual first language acquisition: French and German grammatical development (Vol. 7). John Benjamins Publishing.

Muysken, P., \& Muysken, P. C. (2000). Bilingual speech: A typology of code-mixing. Cambridge University Press.

Noprival, N., Rafli, Z., \& Nuruddin, N. (2019). Breaking the Secrets behind the Polyglots: How Do They Acquire Many Languages?. The Qualitative Report, 24(11), 2916-2928.

Odlin, T. (1989). Language transfer: Cross-linguistic influence in language learning. Cambridge University Press.

Odlin, T. (1990). Word order transfer, metalinguistic awareness, and constraints on foreign language learning. Second language acquisition/foreign language learning, 95-117.

Pavlenko, A. (2004). 'Stop doing that, ia komu skazala!': Language choice and emotions in parent-child communication.Journal of Multilingual and Multicultural Development, 25(2-3), 179-203. https://doi.org/10.1080/ 01434630408666528

Poplack, S., \& Meechan, M. (1998). Introduction: How languages fit together in codemixing. International Journal of Bilingualism,2(2), 127-138. https://doi.org/10.1177/136700699800200201

Poplack, S. (2001). Code-switching (Linguistic). International Encyclopedia of the social and behavioral sciences, 12, 2062-2065. https://doi.org/10.1016/B008-043076-7/03031-X

Poulisse, N., \& Bongaerts, T. (1994). First language use in second language production. Applied Linguistics, 15(1), 36-57. https://doi.org/10.1093/ applin/15.1.36

Reilly, T. (1988). Maintaining Foreign Language Skills.

Reyes, I. (2004). Functions of code switching in schoolchildren's conversations. Bilingual Research Journal, 28(1), 77-98. https://doi.org/10.1080/ 15235882.2004.10162613 
Taeschner, T. (2012). The sun is feminine: A study on language acquisition in bilingual children (Vol. 13). Springer Science \& Business Media.

Tracy, S. J., Geist-Martin, P., Putnam, L. L., \& Mumby, D. K. (2014). Organizing ethnography and qualitative approaches. The SAGE handbook of organizational communication: Advances in theory, research, and methods, 245-269.

Trask, R. L., \& Trask, R. L. (1999). Key concepts in language and linguistics. Psychology Press.Tracy, S. J., Geist-Martin, P., Putnam, L. L., \& Mumby, D. K. (2014). Organizing ethnography and qualitative approaches. The SAGE handbook of organizational communication: Advances in theory, research, and methods, 245-269.

Winford, D. (2003). An introduction to contact linguistics. Wiley-Blackwell.

Yamamoto, M., Ikari, Y., Taura, H., Namba, K.(2014). Introduction to Bilingualism (Bairingarizumu nyuumon). Taishukan: Tokyo, Japan.

Yu, S. (2005). Family factors in bilingual children's code-switching and language maintenance: a New Zealand case study (Doctoral dissertation, Auckland University of Technology).

Yumoto, K. (1995). Bilingualism, Code-switching, Language Mixing, Transfer and Borrowing: Clarifring Terminologies in the Literature. Bulletin of College of Foreign Studies, 17, 49-60.

Zentella, A. C. (1997). Growing up bilingual: Puertorican children in New York. 
The page has been intentionally left blank. 